\title{
Half a Century of Work-Nonwork Interface Research: A Review and Taxonomy of
}

\section{Terminologies}

\begin{abstract}
The extensive interest in the work-nonwork interface over the years has allowed scholars from multiple disciplines to contribute to this literature and to shed light on how professional and personal lives are related. In this paper, we have identified 48 terminologies that describe the interface or relationship between work and non-work, and have organized them into mature, intermediate, and immature categories according to their stage of development and theoretical grounding. We also provide a taxonomy that places worknonwork interface terminologies into a matrix of six cells based on two dimensions: (1) type of nonwork being narrow or broad; and (2) nature of the mutual impact of work and nonwork domains on one another, characterizing the impact as negative, positive, or balanced. The type of nonwork dimension was informed by Frone's (2003) classification of employees' lives into multiple subdomains; the mutual impact dimension was informed by frameworks that organized the literature in part by negative, positive, and balanced work-nonwork interface constructs (e.g., Allen, 2012; Greenhaus \& Allen, 2011). Theoretical contributions of the proposed taxonomy are discussed along with suggestions on important avenues for future research.
\end{abstract}

\section{Keywords}

Work-nonwork; Work-family; Work-home; Role theory; Review; Taxonomy 


\section{Introduction}

"The [work-nonwork interface] field will be held back if we continue to use several overlapping constructs interchangeably to measure phenomena." (Kossek, Baltes, \& Matthews, 2011, p. 359)

The extensive interest in the work-nonwork interface ${ }^{1}$ over the years has allowed scholars from multiple disciplines (i.e., family sociologists, family and marriage therapists, occupational sociologists, vocational psychologists, community psychologists, economists, and industrial and organizational psychologists) to contribute to this literature and to shed light on how professional and personal lives are related (French \& Johnson, 2016; Zedeck, 1992). These scholars used a wide range of terminologies to describe the interrelationships between work and nonwork. While this allows a deep understanding of the dynamics between the two domains, it sometimes causes confusion.

A call for clarifying the work-nonwork interface conceptualizations has been consistent throughout the years in the literature. Zedeck (1992) observed "little coherence" to the literature examining the work and nonwork linkages mainly because much of the research has been conducted by scholars from various disciplines without considering each others' perspectives. More than two decades later, Allen, Cho, and Meier (2014) found the worknonwork interface literature to be "fragmented" (p.112). This fragmentation is due to "variations in the conceptualization, measurement, and treatment of variables across studies" (Parasuraman \& Greenhaus, 2002, p. 300). Furthermore, the low clarity of work-nonwork interface concepts has contributed to inconsistent conclusions about the impact worknonwork research can have in organizations (Kossek, Baltes, \& Matthews, 2011; Kossek \& Ozeki, 1999).

A few articles have attempted to disentangle work-nonwork interface concepts by validating inter-role conflict measures (e.g., Carlson, Kacmar, \& Williams, 2000; Huffman,

\footnotetext{
${ }^{1}$. In this paper, we use work-nonwork interface as an umbrella term to encompass the nuances and variety of work-nonwork conceptualizations that examine the relationship between employee work and nonwork.
} 
Youngcourt, Payne, \& Castro, 2008) and refining construct definitions (e.g., Greenhaus \& Allen, 2011). For example, Lambert (1990) reviewed and organized the linking mechanisms between work and family ${ }^{2}$ in the then growing body of literature. A decade later, Edwards and Rothbard (2000) updated Lambert's work (1990) and presented six types of mechanisms that link work and family: spillover, compensation, segmentation, resource drain, congruence, and conflict. Among other works that attempted to disentangle the worknonwork interface literature or the work-nonwork interface constructs are Allen and colleagues (2014), Demerouti and Geurts (2004), Frone (2003), Greenhaus, Collins, and Shaw (2003), Grzywacz and Marks (2000), Masuda, McNall, Allen, and Nicklin (2012), and Wayne, Butts, Casper, and Allen (2017).

Despite the previous efforts, limitations remain in the use and interpretation of worknonwork interface terms (French \& Johnson, 2016; Kossek, Baltes, \& Matthews, 2011). In addition, many new work-nonwork interface conceptualizations are missing from the aforementioned reviews, and no recent review has organized all the existing terminologies. Currently, if novice researchers develop an interest in the work-nonwork interface, they will be exposed to several concepts that have many aspects in common but differ in others. Hence, there is a need for a comprehensive overview of the available work-nonwork interface terminologies which highlights their theoretical commonalities and differences. Recent interviews with ten influential work-nonwork interface scholars led French and Johnson's (2016) review to conclude that the work-nonwork field needs to further organize its theoretical toolbox by consolidating the theories and trying to clarify concepts that are "actually saying the same thing" (p. 20).

In this paper, we contribute to work-nonwork scholarship in two ways. First, we identify 48 terminologies that describe the interface or relationship between work and

\footnotetext{
${ }^{2}$ We have used the term family rather than nonwork to remain loyal to the verbiage used in the original work.
} 
nonwork, and categorize them as mature, immature, and intermediate according to their stage of development and theoretical grounding. We also provide a taxonomy that places the available work-nonwork interface terminologies into a matrix of six cells based on two dimensions: (1) type of nonwork domain being narrow or broad; and (2) nature of the mutual impact of work and nonwork domains on one another, characterizing impact as negative, positive, or balanced. The type of nonwork dimension was informed by Frone's (2003) classification of employees' lives into multiple subdomains; the mutual impact dimension was informed by frameworks that organized the literature in part by negative, positive, and balanced work-nonwork interface constructs (e.g., Allen, 2012; Greenhaus \& Allen, 2011). We assert that work-nonwork scholarship needs this fresh overview to reconcile the past and to inform the future.

\section{Overview of Work-Nonwork Terminologies}

To generate work-nonwork terminologies, we checked papers that reviewed worknonwork literature and had methodology sections that recorded the different terminologies searched or used to refer to the work-nonwork interface (e.g., Beigi \& Shirmohammadi, 2017; Casper, Eby, Bordeaux, Lockwood, \& Lambert, 2007; Eby, Casper, Lockwood, Bordeaux, \& Brinley, 2005). We also checked the thesaurus sections of the major management and social science electronic databases (e.g., PsycINFO and ABInform), and recorded their suggested keywords for searching work-nonwork issues and the terminologies adopted in the retrieved publications. After screening the search results, we compiled a list of 48 terminologies used in the work-nonwork publications. We next identified the major publications that proposed the idea behind each work-nonwork interface terminology, and we explored the most dominant defintions and measures related to the terminologies. We also searched and located the reviews or meta-analysis papers associated with each work-nonwork interface term. Electronic Appendix 1 presents an overview of the 48 terminologies 
describing the interface or relationship between) work and nonwork. It includes the worknonwork interface terminology, conceptual definitions, pioneering authors, supporting theoretical perspectives, the major measures, and the major review and meta-analysis papers published on each work-nonwork terminology.

In this review, we targeted work-nonwork interface scholarship that "examines the interaction of employee work experiences and [nonwork ${ }^{3}$ ] lives" (Allen, 2012, p. 1163), and we focused on the terminologies generated by scholars to conceptualize the interaction, or interface, between work and nonwork. We would also like to emphasize that the scope of this review captures the literature from the perspective of the worker and not from the perspectives of organizations or social group/system levels.

The 48 work-nonwork terminologies appeared in publications from as early as 1960 through 2011 (for historical reviews of the field see Bianchi \& Milkie, 2010; Bronfenbrenner \& Crouter, 1982; French \& Johnson, 2016; Menaghan \& Parcel, 1990; Perry-Jenkins \& Wadsworth, 2013). The ideas behind the early work-nonwork interface terminologies (e.g., conflict, spillover, and compensation) originated in sources published between 1960 and 1990, when work-nonwork research became a recognized field of study (French \& Johnson, 2016). One critical milestone in the work-nonwork literature during this period was the emergence of role conflict as a distinct construct to account for the interdependence of work and nonwork settings. Seminal works in both sociology (Goode, 1960) and psychology (Kahn, Wolfe, Quinn, Snoek, \& Rosenthal, 1964) drew attention to how work and nonwork roles could pose competing demands on individuals. Pleck (1977) used the term work-family interference and proposed the "work-family role system" (p. 417) to explain the competing mechanism between work and nonwork role responsibilities. During the same period, the expansionist view countered the conflict view by proposing that gains accrued with multiple

\footnotetext{
${ }^{3}$ The original text used family and we changed it to nonwork to avoid confusion.
} 
roles offset the costs of multiple roles and could impact individuals and families in positive ways (Marks, 1977; Sieber, 1974). Along the same line, Kanter (1977) critiqued the myth of separated work and nonwork realms and provoked a generation of future discourse about work-nonwork linkages.

The newborn work-nonwork interface terms (e.g., border, harmony, and articulation) appeared in more recent publications (2000-2011). French and Johnson (2016) referred to the period of 2000 to 2014 as growth and expansion years of the work-nonwork field. For example, having established key terms such as work-family conflict, researchers explored new possibilities and delved deeper into the nuanced interface between professional and personal domains. Here, we only present the pioneering works that provided the origins and definitions of work-nonwork interface conceptualizations. Since extensive literature has been developed around some of these terminologies, it is beyond the scope of this paper to provide a comprehensive list of the authors.

The most frequently used theoretical perspective was role theory and its extensions: role strain theory (Goode, 1960; Kahn et al., 1964), role expansion/accumulation theory (Marks, 1977; Sieber, 1974), role-balance theory (Marks \& MacDermid, 1996), and workfamily role system (Pleck, 1977). Other prominent theoretical perspectives were boundary and border theories (Ashforth, Kreiner, \& Fugate, 2000; Clark, 2000; Nippert-Eng, 1996), ecological systems theory (Bronfenbrenner, 1979), person-environment fit theory (Edwards, Caplan, \& Van Harrison, 1998), the conservation of resources theory (Hobfoll, 1989).

We identified 25 review and meta-analysis articles related to the work-nonwork interface: 13 focused on work-nonwork conflict, five on work-nonwork balance, two on the work-nonwork interface, two on work-nonwork boundary dynamics, one on work-nonwork enrichment, one on work-nonwork facilitation, and one on work-nonwork segmentation and compensation. Our list of terms is by no means complete; however, it can serve as a guiding 
tool for scholars who intend to extend theory-building on the topic, or for novice researchers who are beginning their work-nonwork exploration.

\section{Theoretical and Construct Maturity of Work-Nonwork Interface Terminologies}

Work-nonwork interface terminologies can be placed along a continuum from high to low theoretical and construct maturity, which can be described in terms of three archetypical categories: mature, intermediate, and immature (partially borrowed from Edmondson \& McManus, 2007). Mature work-nonwork interface terminologies encompass well-developed constructs that have been studied over time with increasing precision by a variety of scholars, resulting in clear definitions and operationalized measures used in a larger body of empirical research. For example, work-family conflict possesses a precise definition, and its measures (e.g., Carlson et al., 2000) have been widely used by many researchers (cited 5,956 times on Scopus as of 18 April 2018). Work-family conflict studies have heavily relied on statistical analyses summarized in the existing 13 meta-analyses (e.g., Michel, Kotrba, Mitchelson, Clark, \& Baltes, 2011) and supported by theoretical perspectives (e.g., role strain theory). Other mature terms that have a strong theoretical grounding and have been empirically measured are work-family facilitation (e.g., work-family facilitation scale: Wayne, Musisca, \& Fleeson, 2004), work-family enrichment (work-family enrichment scale: Carlson, Kacmar, Wayne, \& Grzywacz, 2006), work-family positive spillover (work-family positive spillover measure: Hanson, Hammer, \& Colton, 2006), boundary management strategy measure (Kossek, Noe, \& DeMarr, 1999), work-family integration (Work-Family Role IntegrationBlurring Scale: Desrochers, Hilton, \& Larwood, 2005), and work-home interaction (Survey Work-Home Interaction: Demerouti \& Geurts, 2004).

Immature terms are less clearly defined, are not typically supported by a theoretical perspective, and lack formal measures. For example, the terms "work-home interface" (i.e., bidirectional processes between work and home: Ten Brummelhuis \& Bakker, 2012) and 
"work-family interface" (i.e., meaning that family life can interfere with work, and vice versa: Greenhaus \& Ten Brummelhuis, 2013) have been used as "direction of influence" terms rather than formal concepts or constructs. Too often, the terms "interface", and "interaction" have been used interchangeably to refer to the relationship between work and nonwork with no clear conceptual definitions.

Intermediate terms are positioned between mature and immature. Although supported within a theoretical perspective, these terms require further theoretical and empirical development with increasing precision regarding operationalized definitions and formal measurement. For example, work-family accommodation and work-home conflict call for operationalized definitions and formal measures.

Table 1 presents the characteristics of the immature, intermediate, and mature categories, together with terminologies that fit into each group. We are aware that the three categories are not set in stone and that some work-nonwork terminologies might move between categories over time. However, we argue that this categorization will help worknonwork researchers make sense of the existing literature and will enable them to make informed decisions when adopting one or more of the work-nonwork interface terminologies in their scholarly endeavors.

Insert Table 1 about here

\section{Common and Distinguishing Assumptions of Work-Nonwork Interface Terminologies}

Jaccard and Jacoby (2010) argued that when various conceptualizations appear in a work of literature, this signals a potential disagreement among scholars about what constitutes the essence of the phenomenon under investigation. The points of agreement and disagreement are assumed to present the essential core and peripheral properties of the concepts. The points of agreement (called shared meaning) can be contrasted with the 
remaining points (termed surplus meaning) (Jaccard \& Jacoby, 2010). Specific to worknonwork theorizing, Kossek, Baltes, and Matthews (2011) suggested that we can detect the points of disagreement in how we conceptualize the work-nonwork interface terms by examining our language and word choice. The authors invited work-nonwork scholars to broaden and update their language as language powerfully frames how we communicate relevant issues. Also, the choice of one word over others can shape beliefs and attitudes, and most critically, our actions. Based on Jaccard and Jacoby's (2010) notion of shared and surplus meanings, we focused on identifying the similarities and differences among the 48 work-nonwork interface terminologies.

We paid close attention to the use of language defining work-nonwork interface terminologies and the assumptions they implied. The work-nonwork interface terms we reviewed had one assumption in common: work and nonwork are separate entities. In other words, all work-nonwork theories and conceptualizations assume that it is viable to distinguish between work and nonwork activities or resources (e.g., times spent on each) and then to provide a rationale for how the two spheres are linked or related. Although the common assumption that work and work-nonwork are non-overlapping entities was initially identified as a myth by Kanter (1977), the field maintained the assumption, and it has been acknowledged in previous reviews. A review of work-nonwork linkages, published in one of the leading management journals, clearly identified the separation of work and nonwork as an assumption of the review (Edwards \& Rothbard, 2000). Various other work-nonwork scholars have either alluded to this assumption or have shown it in their analyses (e.g. Greenhaus \& Powell, 2006).

Work-nonwork terminologies differed based on two dimensions: type of nonwork and nature of mutual impact. The distinguishing factors enable categorizing the terminologies into a taxonomy. Before presenting the taxonomy, we need to mention that to receive feedback for 
our proposed taxonomy we took two steps. First, we presented the work to a group of seasoned and early-career work-nonwork scholars in an international conference. The discussions that occurred during this session and later the feedback received from the journal reviewers led us to change one dimension of the taxonomy. Second, after revising the taxonomy, we sent it to five leading work-nonwork/career scholars and asked them for feedback. Based on their suggestions and comments, we finalized the taxonomy, which is presented in Figure 1.

The first dimension of our taxonomy reflects assumptions regarding the type of nonwork domain being narrow (e.g., work-family conflict) or broad (e.g., work-nonwork conflict). Although the work aspect is consistent across the reviewed terminologies (i.e., paid employment), the terminologies varied regarding their use of family, life, home, and leisure as the nonwork component. For example, previous studies examined the conflict between work and family (e.g., Greenhaus \& Beutell, 1985), work and life (e.g., Barnes, Lefter, Bhave, \& Wagner, 2016), work and nonwork (e.g., Geurts \& Demerouti, 2003), and work and home (e.g., Demerouti \& Geurts, 2004).

The second dimension refers to assumptions about the mutual impact work and nonwork domains have on one another. In the following sections, we describes these two dimensions, and provide a matrix that places the work-nonwork interface terminologies along categories derived from the distinguishing dimensions. Figure 1 presents the terminologies as placed in the six cells.

Insert Figure 1 about here

\section{Dimension One: Type of Nonwork}

The first distinguishing dimension categorizes the work-nonwork terminologies based on whether their definition of the nonwork domain is narrow or broad. Our categorization 
regarding the type of nonwork is informed by Frone's (2003) review that classified employees' lives into multiple subdomains, including family roles (i.e., spouse, parent, and offspring), and religious, community, leisure, and student roles. We have grouped worknonwork terminologies that define nonwork as being comprised of one specific subdomain (such as family or leisure), under the narrow category, and work-nonwork terminologies that include multiple life subdomains under the broad category. For example, work-family accommodation focuses on family and defines it as "persons related by biological ties, marriage, social custom, or adoption" (Edwards \& Rothbard, 2000, p. 179). Components of the nonwork domain in the broad category can include two or more of the following roles and settings: the nuclear and extended family, friendships, community engagement, and leisure and self-development activities (Greenhaus \& Kossek, 2014). For example, the positive work-nonwork spillover definition involves parenting, community work, and recreation activities (Kirchmeyer, 1992b).

\section{Dimension Two: Nature of Mutual Impact of Work and Nonwork}

The second distinguishing dimension categorizes the nature of mutual impact that work and nonwork domains have on one another as being negative, positive, or balanced. Our categorization regarding the mutual impact of work and nonwork is informed by Allen's (2012) review, which organized the literature in part by negative work-nonwork constructs

(e.g., conflict), positive work-nonwork constructs (e.g., enrichment), and balanced worknonwork constructs (e.g., balance). Following her approach, we have grouped work-nonwork terminologies that are primarily characterized by negative interactions in the negative category. For example, work-nonwork terminologies are categorized as negative that presume an increased engagement in one domain at the expense of reduced involvement in the other (e.g., conflict and compensation), suggest an exchange of limited resources between domains (e.g., resource drain), or describe a separation of the two domains (e.g., segmentation). 
We placed the work-nonwork interface terminologies that are primarily portrayed by positive or synergetic interactions in the positive category. For example, work-nonwork interface terminologies are positive when they define the mutual impact of work and worknonwork as beneficial with resources that can be shared (e.g., enrichment). This includes carryover of positive moods from one domain to the other (e.g., positive spillover). Finally, work-nonwork interface terminologies that do not fall into either the negative or positive categories are placed into the balanced category. Balanced terms describe the line individuals draw between their work and nonwork (e.g., border) or typify an equilibrium of involvement in both work and nonwork that can produce either favorable or unfavorable results (e.g., balance or imbalance, harmony or disharmony).

\section{Taxonomy of Work-Nonwork Terminologies}

In the following sections, we present a taxonomy of the work-nonwork interface terminologies based on the dimensions of type of nonwork (narrow or broad) and nature of mutual impact (negative, positive, or balanced). We have organized each group of positive, negative, and balanced terminologies along a continuum of narrow to broad nonwork categories. In describing the terminologies sitting in the six cells, we have remained loyal to the verbiage used for work and nonwork domains in the original text on each terminology. We hope to bring to the readers' attention how the positive, negative, and balanced terms have used narrow and broad definitions of the nonwork domain. In addition, we have intentionally avoided labelling each cell in the matrix. We are convinced that the literature is saturated with various terms, so we avoided adding further work-nonwork interface conceptualizations.

\section{Negative Mutual Impact: Cells One and Two}

The negative work-nonwork interface terminologies mainly originate from role theory (Kahn et al., 1964), scarcity, spillover, compensatory, and segmentation hypotheses (Goode, 
1960; Kanter, 1977; Wilensky, 1960). The scarcity hypothesis proposed by Goode (1960) suggests that individuals possess a finite amount of time, energy and attention, and that greedy organizations demand the majority of these resources. Therefore, when an individual pursues more roles, the probability of facing situations with conflicting demands increases, and the chance of suffering from negative outcomes such as stress also increases. Wilensky's (1960) spillover hypothesis proposed the idea that negative attitudes and behaviors experienced in one domain result in the same negative attitudes and behaviors in the other domain. The compensatory hypothesis by Wilensky (1960) suggested that workers develop a routine of leisure that compensates for their unsatisfactory work conditions. Segmentation hypothesized that the world of work and nonwork could be kept psychologically and physically separate (Kanter, 1977). These hypotheses provided foundations for an understanding of the negative ways in which work and nonwork impact one another.

The negative mutual impact comprises six terms: accommodation, compensation, conflict, segmentation, spillover, and resource drain. Despite their shared goal to describe the negative relationships between work and nonwork domains, negative work-nonwork terminologies differ in their definitions of what constitutes nonwork. Negative work-nonwork terminologies that use family or leisure limit nonwork to narrow components such as time spent with family members or money spent on leisure activities (see cell one in Figure 1). On the other hand, negative work-nonwork terminologies that use non-work and home instead of family include various nonwork activities such as community and recreation (see cell two). Two negative work-nonwork terminologies (i.e., accommodation and resource drain) offer only narrow definitions of nonwork using the concept of family. However, four negative terms (i.e., compensation, conflict, segmentation, and spillover) have been used for both narrow and broad definitions of nonwork. 


\section{Cell One - Negative and Narrow}

Negative work-nonwork interface terms that focus on one nonwork domain such as family or leisure, fit in cell one: Negative and Narrow. Two negative terms that have been used in conjunction with the narrow term family to define the nonwork domain are workfamily resource drain and work-family accommodation. Resource drain has been defined as the shift of time or attention between work and family domains based on the conservation of resources theory (Goode, 1960). This definition emphasizes the transfer of personal resources (i.e., time, attention, and energy) between family and work domains (Edwards \& Rothbard, 2000, p. 182). On the other hand, in an accommodated work-family relationship, individuals manipulate their involvement with work or family due to dissatisfaction; while in a compensated interaction the individual is prompted to impact the work-family interface because of high involvement in one domain (Edwards \& Rothbard, 2000). Both definitions of work-family resource drain and work-family accommodation stay within the limits of family defined as "persons related by biological ties, marriage, social custom, or adoption" (Edwards \& Rothbard, 2000, p. 179).

We take work-family conflict, as it is commonly studied, as one representative example of having negative and narrow terms and established dimensions and measures (Allen, 2012). Work-family conflict, grounded in role strain theory, describes situations in which the pressures in the work or family role become incompatible with demands from the other role (Greenhaus \& Beutell, 1985). Greenhaus and Beutell (1985) narrowed their conceptualization on family roles (as identified in earlier research on married women by Hall, 1972) and excluded leisure roles from their review.

Scholars have attempted to measure work-family conflict dimensions. The verbiage of quotations illustrating some of the most commonly used measures of work-family conflict suggest that the nonwork domain comprises spouse and children (i.e., nuclear family) and 
responsibilities limited to the household. Examples include the following from Carlson et al.'s (2000) conflict scales: "The demands of my job make it difficult for me to maintain the kind of relationship with my spouse and children that I would like" (time-based-conflict); "When I get home from work I am often too frazzled to participate in family activities/responsibilities" (strain-based-conflict); and "The behaviors I perform that make me effective at work do not help me to be a better parent and spouse" (behavior-based conflict) (pp. 272-273).

Another popular negative term that could be placed in the narrow category is negative work-family spillover. Negative work-family spillover describes negative responses to certain objective conditions of work or family that may be carried into the other domain and affect it negatively (Lambert, 1990). Definitions of negative work-family spillover that limit the carryover of negative affect from household conditions to work and vice versa present a narrow definition of nonwork domain (Edwards \& Rothbard, 2000; Wayne, 2009).

Work-family compensation explicitly refers to the individual's response to unsatisfying work or family conditions by increasing involvement or pursuing rewards in the other role (Dubin, 1956; Edwards \& Rothbard, 2000; Lambert, 1990). For example, decreasing satisfaction with long work hours may encourage parent employees with young children to compensate for the unsatisfactory work conditions by increasing time spend with their young children at home and working part-time. Also, work-family segmentation asserts that the effects of each domain are confined to that sphere, and work or family conditions have no impact on outcomes of the other domain (Frone, 2003; Lambert, 1990). This view is based on the belief that a worker who lets family matters intrude into the workplace is far from an ideal worker, which suggests negative impacts of work and family on one another (Kanter, 1977). Both work-family compensation and work-family segmentation focus on family conditions reflecting a narrow definition of nonwork. 
Work-nonwork conceptualizations of compensation, segmentation, and spillover that equated nonwork with leisure belong to the narrow category as well. These terms originated from sociological theories and studies of how people spent their money in their leisure time (Dubin, 1956; Wilensky, 1960). Based on Wilensky’s (1960) work, Kabanoff (1980) defined two work-leisure compensatory processes (i.e., supplemental and reactive) through which most workers would compensate for deficiencies in their need fulfillment with their leisure activity choices. Kabanoff (1980) also defined spillover as the crossover of negative affects between work and leisure and segmentation as the independence of work and leisure experiences. Kabanoff (1980) offered a task-based definition of leisure as "a set of activities that individuals perform outside of their work context and excludes essential maintenance functions" (p. 69).

Cell Two - Negative and Broad

Negative work-nonwork interface terminologies that regard the nonwork domain as an inclusive construct reaching beyond family roles fit into cell two: negative and broad. Conceptualizations of conflict that advocate a broad nonwork domain use the words nonwork, home, and life as the counter to work. For example, Huffman, Youngcourt, Payne, and Castro (2008) defined work-nonwork conflict as "the extent to which work roles interfere with nonwork roles" (p. 520). Nonwork roles in this definition include various roles that single employees with no children may have outside work. Kreiner (2006) used the term work-home conflict as a more appropriate term than nonwork to include both family and personal life. To measure work-home conflict, he replaced home with the word family in Netemeyer, Boles, and McMurrian's (1996) measure of work-family conflict. Similarly, Hill, Erickson, Holmes and Ferris (2010) used the term work-life conflict "to capture conflict representing incompatibility between work, personal life, and family life" (p.350). Their definition slightly modifies Greenhaus and Beutell's (1985) definition of work-family 
conflict: "participation in work [personal]/family) roles is made more difficult by virtue of participation in the [personal]/family(work) roles" (Hill et al., 2010, p. 350). They used a single statement to measure work-life conflict: "How easy or difficult is it for you to manage the demands of your work and your personal/family life?" (p. 352). Barnes, Lefter, Bhave, and Wagner (2016) included measures of time spent sleeping, on family activities, and on recreation activities (e.g., relaxation and leisure activities) to assess worklife conflict.

The term work/nonwork segmentation postulates that no relationship exists between work and nonwork domain where nonwork can involve any activity "within and beyond the family domain that cannot be simply considered leisure or spare time, because they involve responsibilities (e.g., chores and social obligations)" (Geurts \& Demerout, 2003, p. 281). The term work-home segmentation describes the separation between work and home (Kreiner, 2006). Finally, work-nonwork compensation and negative work-nonwork spillover expand Kabanoff's (1980) definitions of work-leisure compensation and spillover to focus on a broad range of non-work activities (Geurts \& Demerouti, 2003).

\section{Balanced Mutual Impact: Cells Three and Four}

Various theoretical perspectives play a part in understanding the balanced worknonwork interface terminologies. Boundary and border are the two prominent theories that conceptualize the ways people create, maintain, or change perimeters between work and nonwork domains (Ashforth et al., 2000; Clark, 2000). Boundary theory, an extension of the cognitive-social perspective, proposes that people naturally need to draw boundaries to categorize information and make sense of the world around them (Nippert-Eng, 1996, 2008). Border theory was developed within work-nonwork scholarship in response to shortcomings of existing work-nonwork theories (Clark, 2000). Border theory suggests that individuals 
cross temporal, physical, and psychological borders daily as they move between work and home (Clark, 2000).

Another prominent theory in this section is role balance theory which explains that individuals tend to fully engage in the performance of every role in their total role system (Marks \& MacDermid, 1996). Bronfenbrenner's (1979) ecological system theory proposes that work-nonwork phenomena can be influenced by multiple context layers: individual, family, organization, and society. The person-environment fit theory (Edwards et al., 1998) suggests that stress arises not from the person or environment separately, but rather by their fit or congruence with one another. When an individual's capabilities do not match the expectations of a role (work or nonwork), a lack of fit develops, which ultimately leads to stress. Finally, Pleck's (1977) notion of work-family role systems asserts that this role system is composed of male work, female work, male family, and female family roles. Each of these roles may be fully or partially actualized.

The balanced work-nonwork mutual impact category comprises fourteen interface terms: adaptation, articulation, balance, border, boundary, combination, congruence, fit, harmony, interface, interaction, intersection, linkage, and management. Despite their shared characteristic of describing the mutual impact of personal and professional spheres with a generic approach, these terms differ in their definitions of what constitutes nonwork. Balanced work-nonwork terminologies that limit nonwork to family roles are narrow (see cell three). On the other hand, balanced work-nonwork terminologies that use life or home broaden the nonwork domain beyond family roles (see cell four). Seven balanced interface terms, articulation, border, boundary, combination, congruence, linkage, and management offer only narrow definitions; however, two terms, harmony, and adaptation, offer only broad definitions of nonwork. Finally, five balanced terms have been used with use both narrow and 
broad definitions of nonwork by different scholars: balance, fit, interaction, interface, intersection.

\section{Cell Three - Balanced and Narrow}

Balanced work-nonwork interface terms in the third cell encompass various terminologies that imply the use of a narrow definition of nonwork. Work-family balance is a well-recognized balanced term with a variety of definitions. Work-family balance was originally equated with absence of conflict between work and family roles (Frone, 2003). Greenhaus and colleagues (2003) defined balance as "the extent to which individuals are equally involved in - and equally satisfied with - their work role and their family role" (p. 513). Across varied definitions, work-family balance focuses on the overall equilibrium between work and family. Crompton and Brockmann (2007) proposed the work-family life articulation to address shortcomings in the balance argument. They asserted that the topic of work-family balance presumes that if couples manage to combine dual earning with caring responsibilities, balance has been reached. However, individuals and families must struggle with many pressures and tensions to combine employment and family responsibilities. Thus, work-family life articulation is preferred as a "rather more neutral term" (Crompton \& Brockmann, 2007, p. 105). Work-family fit refers to "a form of interrole congruence in which the resources associated with one role are sufficient to meet the demands of another role such that participation in the second role can be effective" (Voydanoff, 2005, p. 825).

Work-family boundary and work-family border are perhaps the most popular terms in the balanced category of terms. Boundary and border concern how individuals maintain, negotiate, and transition across the lines created between work and family/home (Allen et al., 2014). Work-family border assumes that work and family responsibilities are carried out in different times and places and that family domain encompasses border keepers and family members (Clark, 2000, p. 754). Originating from boundary theory, work-family boundary 
and border define the nonwork domain as encompassing children, spouses, partners, elderly parents, or others residing in the same household (Kreiner, 2009; Nippert-Eng, 1996).

Work-family combination and work-family management refer to specific family roles of women and men workers. Neither of these terms have been developed further since their early conceptualization in traditional division of labor perspectives. Corder and Stephan (1984) argued that women and mothers make decisions about how they will combine family and work roles as the first stage in their occupational choice. Similarly, work-family role systems and traditional male and female role perspectives put husbands and fathers in charge of managing their families so that their family responsibilities do not interfere with their work (Pleck, 1977). Likewise, work-family congruence describes the similarities between work and family domains (i.e., household conditions and family roles) based on a third variable, such as dispositional characteristics (Edwards \& Rothbard, 2000).

The final group of balanced terms using narrow definitions of nonwork domain includes work-family interface, interaction, intersection, and linkage. These almost analogous terms have been used interchangeably throughout the literature to label the interface or relationship between work and family. For example, the term work-family interface was equated with work-family conflict in the early writings of work-nonwork (Frone, Russell, \& Cooper, 1992). However, interface has been largely used as an umbrella term to encompass nuances of the work-family relationship (Allen, 2012).

\section{Cell Four-Balanced and Broad}

Balanced work-nonwork interface terms in cell four encompass various terminologies that imply the use of a broad definition of nonwork. For example, the term work-life balance is used to go beyond family domain and include "employees who are not parents but who desire balance for non-work activities such as sports, study, and travel" (Kalliath \& Brough, 2008 p. 323). Therefore, work-life balance includes "all activities in the work and non-work 
domains" (p. 323). Similarly, work-life harmony describes a state of equilibrium where resources gained through work/life enrichment alleviate the stressors arising from work/life conflict (McMillan, Morris, \& Atchley, 2011). McMillan et al. (2011) substitute life with the word family to offer a more inclusive view and to go beyond current definitions of balance.

The next two work-nonwork interface terms in cell four are person-environment fit (Edwards et al., 1998) and ecological system (Bronfenbrenner, 1979). Adaptation regards the social system central to the conceptualization and argues that a work-social system adaptation strategy is used by workers to meet their needs, commitments, responsibilities to "themselves, their families, and others in their social systems" (Voydanoff, 2002, p. 151). Fit, therefore, "reflects the degree to which workers can realize the various dimensions of their work-social system adaptive strategies, given the options available in the workplace" (Barnett, 1998, p. 144).

Work-home interaction encompasses both the negative and positive influences from work to home, and the other way around (Demerouti \& Geurts, 2004). Exemplar quotes from the Work-home Interaction Survey hint at components of family obligations and leisure activities involving family members and friends (a broad definition of nonwork domain). For example, "How often does it happen that you have to cancel appointments with your spouse/family/friends due to work-related commitments?" (Demerouti \& Geurts, 2004, p. 14). Another example is, "How often does it happen that you do not have the energy to engage in leisure activities with your spouse/family/friends because of your job" (Demerouti \& Geurts, 2004, p. 14).

The term work/non-work interface is used as a global concept referring to a "point where "work" and "non-work" meet each other, either in a negative or a positive way" (Geurts \& Demerouti, 2003, p. 279). Similarly, work-home interface refers to bidirectional processes between work and home (Ten Brummelhuis \& Bakker, 2012). The term home is 
used instead of the family because the former acknowledges "the various life roles that employees might possess beyond their work roles" (Ten Brummelhuis \& Bakker, 2012, p. 546). Finally, work-nonwork intersection was used to move toward a broader conceptualization of the work and nuclear family relationship (Greenhaus \& Parasuraman, 1987).

\section{Positive Mutual Impact: Cells Five and Six}

The positive work-nonwork interface terminologies are conceptually related and most of them are built on role accumulation/expansion theory (Marks, 1977; Sieber, 1974) and resource theory (Hobfoll, 1989). Role accumulation theory (Sieber, 1974) emphasizes the advantages or gains from multiple roles that outweigh the disadvantages or costs. Role expansion (Marks, 1977) suggests that the energy in one role can expand to multiple roles, which can result in overall psychological well-being (Marshall \& Barnett, 1993).

Positive mutual impact comprises six terms: enhancement, enrichment, expansion, facilitation, integration, and spillover. Despite similarities in describing positive mutual impact, the positive work-nonwork terminologies differ in their definitions of nonwork domain which range from narrow to broad. Positive work-nonwork terminologies that use family as the counter partner of work provide a narrow definition of nonwork domain (see cell five). On the other hand, positive work-nonwork terminologies that use nonwork and home offer a broad description of nonwork (see cell six). Only one positive work-nonwork term, facilitation, has been used in conjunction with a narrow definition of nonwork as family. Other positive work-nonwork terms have been used by both narrow and broad definitions of nonwork (enhancement, enrichment, expansion, integration, and spillover).

\section{Cell Five - Positive and Narrow}

Positive work-nonwork interface terms that focus on a narrow definition of nonwork fit into cell five. The three terms describing positive mutual impact work-family expansion, 
enhancement, and enrichment use the term family as the counter partner of work; therefore, present a narrow definition. For example, exemplars of one measure of work-family expansion are: "Having both work and family responsibilities makes you a more wellrounded person" and "Working helps you to better appreciate the time you spend with your children” (Marshall \& Barnett, 1993, p. 77). Similarly, the conceptualization of work-family enhancement emphasizes the overall gain in work and family domains and proposes that engagement with the family or work domain may lead to positive moods, self-esteem, or specific skill development that will contribute to an overall enhanced positive mood in the same domain (Wayne, 2009). Finally, work-family enrichment conceptualization suggests that enrichment occurs when individuals use the gains from one domain in the other domain (Wayne, 2009). One dimension of work-family enrichment measure, labeled as work-family capital, hints that involvement in work promotes psychosocial resources that help the individual be a better family member (Carlson et al, 2006).

Positive work-family spillover, which describes the carryover of gains from the family domain to the other (e.g., positive mood), focuses on the transfer of such gains between work and family domains. Four types of positive work-family spillover have been identified in the literature: affective, behavior-based, value-based, and skill-based (Edwards \& Rothbard, 2000; Hanson et al., 2006). In the first type, positive affects (e.g., excitement and happiness) experienced in one role may increase positive effects (e.g., self-efficacy and motivation) in another role, and skills (e.g., interpersonal communication and multitasking) learned in one domain can be effective in the other (Edwards \& Rothbard, 2000). Values learned in one role could influence the general schema of the individual in other roles (Hanson et al., 2006). For example, family culture may influence an individual's work-related values such as work ethic. Behaviors such as a teacher's disciplinary style or a worker's use 
of a communication device (e.g., e-mail or cell phone) may transfer to their behavior at home (Hanson et al., 2006).

Wayne, Grzywacz, Carlson, and Kacmar (2007) proposed a model for work-family facilitation based on positive organizational scholarship, ecological systems, and resource theories. Work-family facilitation regards family as a microsystem and measures its components as parental status, age of the oldest child, and marital status (Grzywacz \& Marks, 2000). The basic premise in the term facilitation is that individuals have natural tendencies to grow, develop, and achieve highest levels of functioning in family and work systems. Because of that tendency toward positivity, individuals, when engaged in work or family roles, obtain resources to enable better functioning (Wayne et al., 2007). Finally, work-family integration refers to "the degree to which work and family roles are synthesized or combined" (Kossek et al., 2011, p. 359).

\section{Cell Six - Positive and Broad}

Positive work-nonwork interface terms that have used non-work, home, and personal life as the counter partner of work fit in the broad category. For example, Kirchmeyer (1992a) examined work-nonwork expansion by focusing on gains generated by hours spent in certain nonwork activities. Her reconceptualization was based on the role expansion/accumulation theory (Sieber, 1974) that suggests four types of benefits for multiple role participation: privileges gained, status security, status enhancement, and enrichment of the personality. The role expansion theory (Sieber, 1974) explains that certain role privileges or rights are institutionalized within each role. Therefore, the greater the number of roles accumulated, the greater the number of privileges that can be enjoyed (Kirchmeyer, 1992a).

In the same vein, Kirchmeyer (1992b) assessed the positive spillover from the nonwork domain (i.e., parenting, community work, and recreation) to work, based on 
Sieber's (1974) theoretical model. Exemplars of quotes from work-nonwork spillover measure suggest three nonwork subdomains: "Being a parent," "Being involved in the community," or "Being involved in recreation/hobby groups" (p. 237). Another positive and broad term is work-nonwork enhancement, which defines the nonwork domain as "nonfamily roles outside work" (Fisher, Bulger, \& Smith, 2009, p. 441). Fisher et al. (2009) developed a measure of work-nonwork enhancement, in which all scale items refer to work-nonwork, as opposed to previous measures that used mixed work-family and work-nonwork items. Workhome enrichment describes "work and home resources increase," where home is used to acknowledge various life roles (Ten Brummelhuis \& Bakker, 2012, p. 545).

Finally, work-nonwork integration describes a situation in which the individual worker is highly involved in work as well as highly involved in nonwork, and vice versa (Staines, 1980). Staines's (1980) conceptualization of nonwork comprised family roles as well as leisure activities. Work-home integration refers to "the merging and blending of various aspects of work and home (Kreiner, 2006, p. 485), where home replaced the word family in three items in order to help respondents think of a broader set of home- and familyrelated activities.

\section{Discussion and Directions for Future Research}

In this paper, we have identified 48 terminologies that describe the interface or relationship between work and nonwork, and have organized them into mature, immature, and intermediate categories in accord with their stage of development and theoretical grounding. In addition, based on the type of nonwork (narrow or broad) and nature of mutual impact (negative positive, or balanced) we have provided a taxonomy that makes better sense of the work-nonwork interface terminologies.

Developing a taxonomy that houses the 48 work-nonwork terminologies in six cells (see Figure 1) is the main contribution of our manuscript. To the best of our knowledge, this 
paper provides the first comprehensive review of work-nonwork interface terminologies. Many of the more recent terminologies were missing from latest reviews (e.g., Demerouti \& Geurts, 2003; Edwards \& Rothbard, 2000; Lambert, 1990). The latest effort to organize variations of work-nonwork terms belongs to Geurts and Demerouti's typology published in 2003, which organized the major work-nonwork theories into classical and recent categories. Geurts and Demerouti's typology (2003) argued that various dimensions based on characteristics of samples studied (i.e., gender, age, marital status and family structure, and educational level, income and race characteristics) can explain the variations in terminologies. Thus, our paper exposes work-nonwork researchers to the diversity of the work-nonwork relationship conceptualizations and provides a conceptual map for navigating the literature and planning further research. Our typology will enable future work-nonwork researchers to make more informed decisions about the interface terminologies they select. Mindful selection of work-nonwork terminologies will pave the way for improving research designs and developing precise measurements.

We partially attribute the existence of 48 terminologies (some of which have a relatively high conceptual overlap) to the interdisciplinary nature of the work-nonwork topic. Scholars in management, sociology, applied psychology, family studies, human resource development, and economics (among other disciplines) regard work-nonwork as one of their core topics and have contributed to this scholarship (Korabik, Lero, \& Whitehead, 2011; MacDermid, Harvey, Pitt-Catsouphes, Kossek \& Sweet, 2006). This is a positive attribute of the work-nonwork topic, because adopting multiple interdisciplinary lenses to the study of a topic enriches our understanding of it and uncovers angles that could otherwise remain unknown (Kossek, Baltes, \& Matthews, 2011). However, we have noticed a possible lack of cross-disciplinary discourse among work-nonwork scholars; this has led to the proliferation of work-nonwork terminologies with insufficient theoretical grounding and to duplication of 
concepts that have already been used by other researchers from other relevant disciplines. Therefore, another contribution of this paper is that it brings together the different worknonwork terminologies generated in multiple disciplines; this should help to reduce the messiness of the work-nonwork discipline and to avoid repetitive conceptualizations in the work-nonwork literature. Furthermore, by organizing the work-nonwork terminologies under immature, intermediate, and mature categories, scholars can further develop theories and measures for those work-nonwork terminologies in the immature and intermediate categories. This could facilitate synthesis of work-nonwork terminologies and provide better opportunities for comparison of research findings, hence supporting the overall development of the discipline.

Our review reveals that five out of the six mature work-nonwork interface terminologies have focused on family, which is a narrow type of nonwork (i.e.,work-family boundary, work-family conflict, work-family enrichment, work-family facilitation, and positive work-family spillover). All five are relatively recent (Ashforth et al., 2000; Greenhaus \& Powell, 2006; Grzywacz, 2002). This suggests that it might have been more viable for work-nonwork scholars to theorize, define boundaries, and measure family than to address other nonwork domains such as life or leisure. Even among the intermediate and immature terminologies, a narrow perspective toward nonwork is more frequent. However, recent works of leading work-nonwork scholars (e.g., Ten Brummelhuis \& Bakker, 2012) are moving toward broad perspectives. We encourage future scholars to take steps to operationalize and establish formal measures for nonwork domains other than family.

Our taxonomy of balanced terms indicates an interest in theorizing work-nonwork interface that recognizes both negative and positive mutual impacts of work-nonwork spheres. The balanced category encompasses 20 terms compared to 16 negative and 12 positive categories; however, 14 of the balanced terms appear in immature, 4 appear in 
intermediate, and 2 appear in mature categories. We encourage future researchers to invest in advancing the theoretical grounds and measures of the terms in the balanced category. The present state of work-nonwork research reflects a duality in either adopting a negative or positive perspective in the study of the work and nonwork interface (Allen, 2012; Greenhaus \& Allen, 2011). Theorizing the balanced terms can move the work-nonwork field into a new era.

The distinction between narrow and broad conceptualizations of the nonwork domain hint to an ongoing debate in the work-nonwork field, which has been acknowledged by several authors over the years (e.g., Bennett, Beehr, \& Ivanitskaya, 2017; Casper, Marquardt, Roberto, \& Buss, 2016; Parasuraman \& Greenhaus, 2002; Huffman et al., 2008; Rothausen, 1999). We contribute to this debate by drawing on shared meanings of what constitutes nonwork and the points of disagreement among scholars about the use of various nonwork terms (e.g., family or home). As Kossek, Baltes, and Matthews (2011) suggested, detecting points of disagreement in the language and in word choice increases understanding of how nonwork has been conceptualized. The choice of narrow or broad words to refer to the nonwork domain makes us wonder if such distinction is needed. Is it necessary to diversify the labels used to refer to life components beyond work? Do we have to distinguish between family and home? Future researchers can develop measures of the work-nonwork interface that assess multiple components of the nonwork domain to enable analysis of the interfaces between work and different nonwork activities.

The nature of the mutual impact dimension of the matrix shows a fairly equal distribution of positive and negative ends. We attribute this balance to the evolving nature of work, family, and their interface in recent decades. Work-nonwork theorizing started after the industrial revolution when the "interplay between labor and leisure became a major problem" (Wilensky, 1960, p. 543); this in turn initiated a separation between employees' work and 
family spheres (Lambert, 1990). Prior to industrial advancements, work was integrated into the general activities that families undertook to survive (Edgell, 2012). Industrialization gradually forced employees to split their work and nonwork lives into segregated domains, resulting in most conceptualizations embracing the notion of substitution. At the time, the negative mutual impact emanated from role and stress theories that positioned work and family as competitors for a person's time and energy (Kahn et al., 1964). Later, changes in technology and work arrangements, increases in the number of female workers and dualearner couples, and other changes in employee demographics led to a proliferation of worknonwork terminologies; hence, work-nonwork scholarship evolved to embrace and theorize the positive view. Future work-nonwork theorists might consider the increasing prevalence of the internet, the constant connectedness experienced by workers (e.g., Christensen, 2009; Wajcman \& Rose, 2011), and the fading boundaries between work and family. These developments call for enhanced integration between work and family (e.g., Ashforth et al., 2000), and for models that accommodate contemporary work-nonwork interface modes.

Moving away from seeing work and nonwork as having negative mutual impacts on one another (i.e., competitors) to investing in their positive associations is also aligned with the movement during recent decades towards the ecological systems approach (Bronfenbrenner, 1979) and positive organizational scholarship (Cameron, Dutton, Quinn, \& Wrzesniewski, 2003). Academic interest in systems theory (Bronfenbrenner, 1979) has been extended to work-nonwork scholarship to conceptualize the interactions of the work and family microsystems (comprising roles and relationships) that create a combined effect on work, family, and individual outcomes (Voydanoff, 2002). Similarly, positive organizational scholarship, concerned with the study of positive processes and outcomes, has drawn worknonwork scholars' attention to how experiences at home may make the person a better employee, and how being an employee may help the person be a better parent or partner 
(Cameron et al., 2003). From this lens, holding multiple roles (e.g., worker, parent, and partner) can help increase alternative resources and generate positive consequences that outweigh the work-nonwork strain (Spreitzer, Grzywacz, \& Demerouti, 2013). The emphasis on additive effects and generative positive consequences helps to explain why work and nonwork relationships may enable positive rather than negative effects.

As the number and variety of work-nonwork initiatives and policies grow (Kossek et al., 2011), our taxonomy can inform organizational practitioners to be mindful about selecting the right terms as the choice of one word over others changes meaning of worknonwork concepts (Bennett et al., 2017; Kossek et al., 2011). For example, an intervention labeled as work-life balance can signal a broad emphasis on nonwork domain (encompassing family as well as leisure activities) that can target married, single, caregiver employees whereas a program labeled as work-family balance communicates a narrow focus on employees with family responsibilities as parents and spouses.

We acknowledge that some scholars in the field might regard our taxonomy as incomplete (i.e., research needs to be done to test it), inadequate (i.e., it fails to incorporate all the important perspectives), or inaccurate (i.e., it fails to acknowledge incommensurable features). However, we argue that this paper takes one step forward in promoting theory-building in the work-nonwork field by organizing the huge number of multiple terminologies that have conceptualized the same phenomena of the work-nonwork interface. As the opening quote pointed out, "the field will be held back if we continue to use several overlapping constructs interchangeably to measure phenomena" (Kossek, Baltes, \& Matthews, 2011, p. 359). We thus set the stage for both dialogue and disagreement in the further development of the field.

\section{Acknowledgement}


This work was supported by the British Academy of Management under the Leverhulme Small Research Grants - SRG 2015-16 Round.

\section{References}

Allen, T. D. (2012). The work-family interface. In Steve W. J. Kozlowski (Ed.), Oxford Handbook of Industrial and Organizational Psychology (pp. 1163-1198). Oxford: Oxford University Press.

Allen, T. D., Cho, E., \& Meier, L. L. (2014). Work-family boundary dynamics. The Annual Review of Organizational Psychology and Organizational Behavior, 1(1), 99-121.

Arthur, M. B., \& Rousseau, D. M. (2001). The boundaryless career: A new employment principle for a new organizational era. New York: Oxford University Press.

Ashforth, B. E., Kreiner, G. E., \& Fugate, M. (2000). All in a day's work: Boundaries and micro role transitions. Academy of Management Review, 25(3): 472-491.

Bennett, M. M., Beehr, T. A., \& Ivanitskaya, L. V. (2017). Work-family conflict: Differences across generations and life cycles. Journal of Managerial Psychology, 32(4), 314-332.

Barnes, C. M., Lefter, A. M., Bhave, D. P., \& Wagner, D. T. (2016). The benefits of bad economies: Business cycles and time-based work-life conflict. Journal of Occupational Health Psychology, 21(2), 235.

Barnett, R. C. (1998). Toward a review and reconceptualization of the work/family literature. Genetic, Social, and General Psychology Monographs, 124(2), 125-182.

Beigi, M. \& Shirmohammadi, M. (2017). Qualitative Research on Work-Family in the Management Field: A Review. Applied Psychology: An International Review. doi: 10.1111/apps. 12093

Bianchi, S. M., \& Milkie, M. A. (2010). Work and family research in the first decade of the 21st century. Journal of Marriage and Family, 72(3), 705-725. 
Bowen, G. L. (1998). Effects of leader support in the work unit on the relationship between work spillover and family adaptation. Journal of Family and Economic Issues, 19(1), $25-52$.

Bronfenbrenner, U. (1979). The ecology of human development: Experiments by nature and design. Cambridge, Mass: Harvard University Press.

Bronfenbrenner, U., \& Crouter, A. C. (1982). Work and family through time and space. In Sheila B. Kamerman and Cheryl D. Hayes, Families that work: children in a changing world, National Academy Press.

Cameron, K. S., Dutton, J. E., Quinn, R. E., \& Wrzesniewski, A. (2003). Positive organizational scholarship: Foundations of a new discipline. San Francisco: BerrettKoehler Publishers.

Carlson, D. S., Kacmar, K. M., \& Williams, L. J. (2000). Construction and initial validation of a multidimensional measure of work-family conflict. Journal of Vocational behavior, 56(2), 249-276.

Carlson, D. S., Kacmar, K. M., Wayne, J. H., \& Grzywacz, J. G. (2006). Measuring the positive side of the work-family interface: Development and validation of a workfamily enrichment scale. Journal of Vocational Behavior, 68(1), 131-164.

Casper, W. J., Eby, L. T., Bordeaux, C., Lockwood, A., \& Lambert, D. (2007). A review of research methods in IO/OB work-family research. Journal of Applied Psychology, 92(1), 28.

Christensen, T. H. (2009). Connected presence in distributed family life. New Media \& Society, 11(3), 433-451.

Clark, S. C. (2000). Work/family border theory: A new theory of work/family balance. Human Relations, 53(6), 747-770. 
Corder, J., \& Stephan, C. W. (1984). Females' combination of work and family roles: Adolescents' aspirations. Journal of Marriage and the Family, 46(2), 391-402.

Crompton, R., \& Brockmann, M. (2007). Class, gender and work-life articulation. Gender divisions and working time in the new economy: Changing patterns of work, care and public policy in Europe and North America (pp. 103-121). UK: Globalization and Welfare.

Crouter, A. C. (1984). Spillover from family to work: The neglected side of the work-family interface. Human Relations, 37(6), 425-441.

Demerouti, E., \& Geurts, S. (2004). Towards a typology of work-home interaction. Community, Work \& Family, 7(3), 285-309.

Dubin, R. (1956). Industrial Workers' Worlds: a study of the central life interests of industrial workers. Social Problems, 3(3), 131-142.

Eby, L. T., Casper, W. J., Lockwood, A., Bordeaux, C., \& Brinley, A. (2005). Work and family research in IO/OB: Content analysis and review of the literature (1980-2002). Journal of Vocational Behavior, 66(1), 124-197.

Edgell, S. P. (2012). The sociology of work: Continuity and change in paid and unpaid work, London: Sage.

Edmondson, A. C., \& McManus, S. E. (2007). Methodological fit in management field research. Academy of Management Review, 32(4), 1246-1264.

Edwards, J. R., \& Rothbard, N. P. (2000). Mechanisms linking work and family: Clarifying the relationship between work and family constructs. Academy of Management Review, 25(1), 178-199.

Edwards, J. R., Caplan, R. D., \& Van Harrison, R. (1998). Person-environment fit theory. Theories of Organizational Stress, 28, 67. 
Fisher, G. G., Bulger, C. A., \& Smith, C. S. (2009). Beyond work and family: A measure of work/nonwork interference and enhancement. Journal of Occupational Health Psychology, 14(4), 441.

French, K. A., \& Johnson, R. C. (2016). A Retrospective Timeline of the Evolution of WorkFamily Research. In Tammy D. Allen and Lillian T. Eby. The Oxford Handbook of Work and Family (pp. 9-22). Oxford: Oxford University Press.

Frone, M. R. (2003). Work-family balance. In J. C. Quick and L. E. Tetrick. Handbook of Occupational Health Psychology (pp. 143-162). Washington, DC: American Psychological Association.

Frone, M. R., Russell, M., \& Cooper, M. L. (1992). Antecedents and outcomes of workfamily conflict: Testing a model of the work-family interface. Journal of Applied Psychology, 77(1), 65.

Geurts, S. A., \& Demerouti, E. (2003). Work/non-work interface: A review of theories and findings. The Handbook of Work and Health Psychology, 2, 279-312.

Geurts, S. A., \& Demerouti, E. (2004). Work/non- work interface: a review of theories and findings. The Handbook of Work and Health Psychology, Second Edition, 279-312.

Goode, W. J. (1960). A theory of role strain. American Sociological Review, 25, 483-496.

Greenhaus, J. H., \& Allen, T. D. (2011). Work-family balance: A review and extension of the literature. In J. C. Quick and L. E. Tetrick, Handbook of Occupational Health Psychology (pp. 165-183). Washington, DC: American Psychological Association.

Greenhaus, J. H., \& Beutell, N. J. (1985). Sources of conflict between work and family roles. Academy of Management Review, 10(1), 76-88.

Greenhaus, J. H., \& Parasuraman, S. (1987). A work-nonwork interactive perspective of stress and its consequences. Journal of Organizational Behavior Management, 8(2), $37-60$. 
Greenhaus, J. H., \& Powell, G. N. (2006). When work and family are allies: A theory of work-family enrichment. Academy of Management Review, 31(1), 72-92.

Greenhaus, J. H., \& Ten Brummelhuis, L. L. (2013). Models and frameworks underlying work-life research. In D. A. Major \& R. Burke (Eds.), Handbook of work-life integration of professionals: Challenges and opportunities (pp. 14-34). Northampton, MA: Edward Elgar.

Greenhaus, J. H., Collins, K. M., \& Shaw, J. D. (2003). The relation between work-family balance and quality of life. Journal of Vocational Behavior, 63(3), 510-531.

Grzywacz, J. (2002). Toward a theory of work-family facilitation. Paper presented at 34th Annual Theory Construction and Research Methodology Workshop, Houston, Texas. Retrieved from: https://archive.ncfr.org/tcrm-archive/tcrm_2002_grzywacz

Grzywacz, J. G., \& Marks, N. F. (2000). Reconceptualizing the work-family interface: An ecological perspective on the correlates of positive and negative spillover between work and family. Journal of Occupational Health Psychology, 5(1), 111-126.

Hanson, G. C., Hammer, L. B., \& Colton, C. L. (2006). Development and validation of a multidimensional scale of perceived work-family positive spillover. Journal of Occupational Health Psychology, 11(3), 249.

Hill, E. J., Erickson, J. J., Holmes, E. K., \& Ferris, M. (2010). Workplace flexibility, work hours, and work-life conflict: Finding an extra day or two. Journal of Family Psychology, 24(3), 349.

Hobfoll, S. E. (1989). Conservation of resources: A new attempt at conceptualizing stress. American Psychologist, 44(3), 513.

Huffman, A. H., Youngcourt, S. S., Payne, S. C., \& Castro, C. A. (2008). The importance of construct breadth when examining interrole conflict. Educational and Psychological Measurement, 68(3), 515-530. 
Jaccard, J., \& Jacoby, J. (2010). Theory construction and model-building skills: A practical guide for social scientists. New York: Guilford Press.

Kabanoff, B. (1980). Work and nonwork: A review of models, methods, and findings. Psychological Bulletin, 88(1), 60.

Kahn, R. L., Wolfe, D. M., Quinn, R. P., Snoek, J. D., \& Rosenthal, R. A. (1964). Organizational stress: Studies in role conflict and ambiguity. New York: Wiley.

Kalliath, T., \& Brough, P. (2008). Work-life balance: A review of the meaning of the balance construct. Journal of Management \& Organization, 14(03), 323-327.

Kanter, R. M. (1977). Work and family in the United States: A critical review and agenda for research and policy. New York: Russell Sage Foundation.

Kirchmeyer, C. (1992a). Perceptions of nonwork-to-work spillover: Challenging the common view of conflict-ridden domain relationships. Basic and Applied Social Psychology, 13(2), 231-249.

Kirchmeyer, C. (1992b). Nonwork participation and work attitudes: A test of scarcity vs. expansion models of personal resources. Human Relations, 45(8), 775-795.

Korabik, K., Lero, D. S., \& Whitehead, D. L. (2011). Handbook of work-family integration: Research, theory, and best practices. Ontario: Academic Press.

Kossek, E. E., \& Ozeki, C. (1999). Bridging the work-family policy and productivity gap: A literature review. Community, Work \& Family, 2(1), 7-32.

Kossek, E. E., Baltes, B. B., \& Matthews, R. A. (2011). How work-family research can finally have an impact in organizations. Industrial and Organizational Psychology, 4(3), 352-369. 
Kossek, E., Noe, R., \& DeMarr, B. (1999). Work-family role synthesis: Individual, family and organizational determinants. International Journal of Conflict Resolution, 10, $102-129$.

Kreiner, G. E. (2006). Consequences of work- home segmentation or integration: A personenvironment fit perspective. Journal of organizational behavior, 27(4), 485-507.

Lambert, S. J. (1990). Processes linking work and family: A critical review and research agenda. Human Relations, 43(3), 239-257.

MacDermid, S., Harvey, A. Pitt-Catsouphes, M., Kossek, E., Sweet, S. (2006). The workfamily handbook: Multi-disciplinary perspectives and approaches (pp. 238-308). The work-family conflict construct: Methodological implications. Mahwah, NJ: Erlbaum.

Marks, S. R. (1977). Multiple roles and role strain: Some notes on human energy, time and commitment. American Sociological Review, 921-936.

Marks, S. R., \& MacDermid, S. M. (1996). Multiple roles and the self: A theory of role balance. Journal of Marriage and the Family, 417-432.

Marshall, N. L., \& Barnett, R. C. (1993). Work-family strains and gains among two-earner couples. Journal of Community Psychology, 21(1), 64-78.

Masuda, A. D., McNall, L. A., Allen, T. D., \& Nicklin, J. M. (2012). Examining the constructs of work-to-family enrichment and positive spillover. Journal of Vocational Behavior, 80(1), 197-210.

McMillan, H. S., Morris, M. L., \& Atchley, E. K. (2011). Constructs of the work/life interface: A synthesis of the literature and introduction of the concept of work/life harmony. Human Resource Development Review, 10(1), 6-25.

McNall, L. A., Nicklin, J. M., \& Masuda, A. D. (2010). A meta-analytic review of the consequences associated with work-family enrichment. Journal of Business and Psychology, 25(3), 381-396. 
Menaghan, E. G., \& Parcel, T. L. (1990). Parental employment and family life: Research in the 1980s. Journal of Marriage and the Family, 52(4), 1079-1098.

Michel, J. S., Kotrba, L. M., Mitchelson, J. K., Clark, M. A., \& Baltes, B. B. (2011). Antecedents of work-family conflict: A meta-analytic review. Journal of Organizational Behavior, 32(5), 689-725.

Michel, J. S., Mitchelson, J. K., Kotrba, L. M., LeBreton, J. M., \& Baltes, B. B. (2009). A comparative test of work-family conflict models and critical examination of workfamily linkages. Journal of Vocational Behavior, 74(2), 199-218.

Nippert-Eng, C. (1996). Calendars and keys: The classification of "home" and "work". In Sociological Forum (pp. 563-582). Netherlands: Springer.

Nippert-Eng, C. E. (2008). Home and work: Negotiating boundaries through everyday life. Chicago: University of Chicago Press.

Parasuraman, S., \& Greenhaus, J. H. (2002). Toward reducing some critical gaps in workfamily research. Human Resource Management Review, 12(3), 299-312.

Perry-Jenkins, M., \& Wadsworth, S. M. (2013). Work and family through time and space: Revisiting old themes and charting new directions. In Gary W. Peterson \& Kevin R. Bush (Eds.), Handbook of Marriage and the Family (pp. 549-572). Springer.

Pleck, J. H. (1977). The work-family role system. Social Problems, 24(4), 417-427.

Sieber, S. D. (1974). Toward a theory of role accumulation. American Sociological Review, 39(4), 567-578.

Spreitzer, G. M., Grzywacz, J. G., \& Demerouti, E. (2013). Using a positive organizational scholarship lens to enrich research on work-family relationships. New frontiers in work and family research. New York: Psychology Press.

Staines, G. L. (1980). Spillover versus compensation: A review of the literature on the relationship between work and nonwork. Human Relations, 33(2), 111-129. 
Sweet, S., \& Moen, P. (2006). Advancing a Career Focus on Work and Family: Insights from the Life Course Perspective. In M. Pitt-Catsouphes, E. E. Kossek, and S. Sweet (Ed.), The Work and Family Handbook: Multi-Disciplinary Perspectives and Approaches (pp. 189-208). Mahwah, NJ: Lawrence Erlbaum Associates.

Ten Brummelhuis, L. L., \& Bakker, A. B. (2012). A resource perspective on the work-home interface: The work-home resources model. American Psychologist, 67(7), 545.

Voydanoff, P. (2002). Linkages between the work-family interface and work, family, and individual outcomes an integrative model. Journal of Family Issues, 23(1), 138-164.

Voydanoff, P. (2005). Toward a conceptualization of perceived work-family fit and balance: A demands and resources approach. Journal of Marriage and Family, 67(4), 822-836.

Wajcman, J., \& Rose, E. (2011). Constant connectivity: Rethinking interruptions at work. Organization Studies, 32(7), 941-961.

Wayne, J. H. (2009). Reducing conceptual confusion clarifying the positive side of work and family. In D. R. Crane \& J. E. Hill, Handbook of families and work: Interdisciplinary perspectives (pp. 105-140). New York: University Press of America.

Wayne, J. H., Butts, M. M., Casper, W. J., \& Allen, T. D. (2017). In search of balance: a conceptual and empirical integration of multiple meanings of work-family balance. Personnel Psychology. 70, 167-210.

Wayne, J. H., Grzywacz, J. G., Carlson, D. S., \& Kacmar, K. M. (2007). Work-family facilitation: A theoretical explanation and model of primary antecedents and consequences. Human Resource Management Review, 17(1): 63-76.

Wilensky, H. L. (1960). Work, careers and social integration. International Social Science Journal. 12(4): 543-560.

Zedeck, S. (1992). Introduction: Exploring the domain of work and family concerns. San Francisco: Jossey-Bass. 
Table 1. Theoretical and construct maturity of work-nonwork interface terminologies

\begin{tabular}{|c|c|c|c|}
\hline Categories & Immature & Intermediate & Mature \\
\hline $\begin{array}{l}\text { Characteristics } \\
\text { Definition } \\
\text { Measurement Theory }\end{array}$ & $\begin{array}{l}\text { Not clearly defined } \\
\text { No formal measures } \\
\text { Atheoretical }\end{array}$ & $\begin{array}{l}\text { One/more definitions } \\
\text { No/Adhoc formal } \\
\text { measures } \\
\text { Developing } \\
\text { theoretical ground }\end{array}$ & $\begin{array}{l}\text { Clearly defined } \\
\text { Established formal } \\
\text { measures } \\
\text { Solid theoretical } \\
\text { ground }\end{array}$ \\
\hline $\begin{array}{l}\text { Work-Nonwork } \\
\text { Interface } \\
\text { Terminologies }\end{array}$ & $\begin{array}{l}\text { Work-social system } \\
\text { adaptation } \\
\text { Work-social system fit } \\
\text { Work-family } \\
\text { articulation } \\
\text { Work-family } \\
\text { combination } \\
\text { Work-family harmony } \\
\text { Work-family interaction } \\
\text { Work-family interface } \\
\text { Work-family } \\
\text { intersection } \\
\text { Work-family linkage } \\
\text { Work-family } \\
\text { management } \\
\text { Work-leisure } \\
\text { compensation } \\
\text { Work-leisure } \\
\text { segmentation } \\
\text { Work-leisure spillover } \\
\text { Work-home } \\
\text { segmentation } \\
\text { Work-life balance } \\
\text { Work-life harmony } \\
\text { Work-nonwork } \\
\text { compensation } \\
\text { Work/non-work } \\
\text { segmentation } \\
\text { Work-nonwork } \\
\text { spillover (Negative) } \\
\text { Work/non-work } \\
\text { interface } \\
\text { Work-home interface } \\
\text { Work non-work } \\
\text { intersection }\end{array}$ & $\begin{array}{l}\text { Work-family } \\
\text { accommodation } \\
\text { W-family balance } \\
\text { Work-family border } \\
\text { Work-family } \\
\text { congruence } \\
\text { Work-family } \\
\text { compensation } \\
\text { Work-family } \\
\text { enhancement } \\
\text { Work-family } \\
\text { expansion } \\
\text { Work-family } \\
\text { integration } \\
\text { Work-family fit } \\
\text { Work-family } \\
\text { resource drain } \\
\text { work-family } \\
\text { segmentation } \\
\text { Work-family } \\
\text { spillover (negative) } \\
\text { Work-home conflict } \\
\text { Work-nonwork } \\
\text { conflict } \\
\text { Work/nonwork } \\
\text { expansion } \\
\text { work-nonwork } \\
\text { enhancement } \\
\text { Work-nonwork } \\
\text { spillover (positive) } \\
\text { Work-nonwork } \\
\text { integration } \\
\text { Work-home } \\
\text { enrichment } \\
\text { work-nonwork } \\
\text { enhancement }\end{array}$ & $\begin{array}{l}\text { Work-family boundary } \\
\text { Work-family conflict } \\
\text { Work-family } \\
\text { enrichment } \\
\text { Work-family } \\
\text { facilitation } \\
\text { Work-family spillover } \\
\text { (positive) } \\
\text { Work-home interaction }\end{array}$ \\
\hline
\end{tabular}

Note: Work-Nonwork interface terminologies are listed alphabetically in each category. 
Figure 1. Taxonomy of work-nonwork interface terminologies

Type of Nonwork

\begin{tabular}{|c|c|c|}
\hline & Narrow & Broad \\
\hline Negative & $\begin{array}{l}\quad \text { Cell One } \\
\text { Work-family accommodation } \\
\text { Work-family compensation } \\
\text { Work-family conflict } \\
\text { Work-family segmentation } \\
\text { Work-family spillover (negative) } \\
\text { Work-family resource drain } \\
\text { Work/leisure compensation } \\
\text { Work/leisure segmentation } \\
\text { Work/leisure spillover }\end{array}$ & \begin{tabular}{l}
\multicolumn{1}{c}{ Cell Two } \\
Work-home conflict \\
Work-home segmentation \\
Work-life conflict \\
Work-nonwork compensation \\
Work-nonwork conflict \\
Work/non-Work segmentation \\
Work nonwork spillover (negative)
\end{tabular} \\
\hline Balanced & \begin{tabular}{l}
\multicolumn{1}{c}{ Cell Three } \\
Work-family life articulation \\
Work-family balance \\
Work-family border \\
Work-family boundary \\
Work-family combination \\
Work-family congruence \\
Work-family fit \\
Work-family interface \\
Work-family interaction \\
Work-family intersection \\
Work-family linkage \\
Work-family management
\end{tabular} & \begin{tabular}{l}
\multicolumn{1}{c}{ Cell Four } \\
Work-life balance \\
Work-life harmony \\
Work-social system adaptation \\
Work-social system fit \\
Work-home interaction \\
Work/non-work interface \\
Work-home interface \\
Work-nonwork intersection
\end{tabular} \\
\hline Positive & \begin{tabular}{l}
\multicolumn{1}{c}{ Cell Five } \\
Work-family expansion \\
Work-family enhancement \\
Work-family enrichment \\
Work-family facilitation \\
Work-family integration \\
Work-family spillover (positive)
\end{tabular} & \begin{tabular}{l}
\multicolumn{1}{c}{ Cell Six } \\
Work-home enrichment \\
Work/nonwork expansion \\
Work/nonwork enhancement \\
Work-nonwork integration \\
Work-home integration \\
Nonwork-to-work spillover \\
(positive)
\end{tabular} \\
\hline
\end{tabular}

